\title{
Body Size and Behaviour Traits of Dogs in Czech Households
}

\author{
Eva Baranyiová ${ }^{1}$, Antonín Holub, Mojmír Tyrlík² \\ ${ }^{1}$ Department of Veterinary Public Health and Toxicology, Faculty of Veterinary Hygiene and Ecology, \\ University of Veterinary and Pharmaceutical Sciences, Brno, Czech Republic \\ ${ }^{2}$ Department of Psychology, Faculty of Arts, Masaryk University, Brno
}

Received April 29, 2008

Accepted December 15, 2008

\begin{abstract}
The objective of this study was to analyse the effect of body size of dogs on their coexistence with humans in Czech households. For this purpose we used questionnaire data on 246 dogs indicating the breed. The dogs were divided into five body size groups, i.e. toy (T, up to $5 \mathrm{~kg}$ body mass, $\mathrm{n}=32)$, small $(\mathrm{S}, 5-10 \mathrm{~kg}$ body mass, $\mathrm{n}=52)$, medium size $(\mathrm{M}, 10-17 \mathrm{~kg}$ body mass, $\mathrm{n}=39$ ), large ( $\mathrm{L}, 17-33 \mathrm{~kg}$ body mass, $\mathrm{n}=70)$, giant $(\mathrm{G}$, over $33 \mathrm{~kg}$ body mass, $\mathrm{n}=53$ ). The largest dogs surpassed the body mass of the smallest dogs at least seven times, and giant dogs weighed at least one half and toy dogs less than one tenth of the average body mass of people in the Czech human population. Despite this the majority of the studied traits regardless of body mass of the dogs showed no significant differences. In the vast majority of Czech households all dogs were considered household members, taken on travels or vacations, photographed and their birthdays were celebrated. Aggressiveness of the dogs did not correlate with their body size.

Among the 84 traits of the behaviour of dogs and their owners, which were analysed, only 23 , i.e. $27.4 \%$ traits were significantly related to their body mass. Larger and heavier dogs were more frequently kept in houses with yards and gardens, in rural environments. Toy and small dogs prevailed in urbanised environments, in apartments. They were allowed to use furniture, sleep in beds of household members. Moreover, toy dogs predominated in one-person households.

Large dogs were more often trained, sometimes by professional trainers, obeyed commands better and were more often described as obedient. They were considered not only as companions but also as working dogs. Giant size dogs were also more often trained to be protective.

These data show that the differences in the body size of dogs modified their co-existence with humans only to a limited extent.
\end{abstract}

Canis lupus familiaris, body size, giant, large, medium, small, toy, questionnaire

At present there are more than 400 breeds of dogs, each of them developed to carry out a particular activity (Stafford 2007). Many of them are kept as companions and are no longer used for their original purpose (Baranyiová et al. 2005; Stafford 2007). The statement "emphasis on physical characteristics may have led breeders to pay insufficient attention to behaviour" (Stafford 2007) has been supported by the fact that canine behaviour is increasingly becoming a focus of attention for several reasons. Veterinarians and behaviourists are confronted with a number of problems, such as separation anxiety, especially in urban dogs (e.g. Flannigan and Dodman 2001; Takeushi et al. 2001) and compulsive behaviours (Luescher 2002, 2003). However, the most serious problem of human-dog co-existence is canine aggression (e.g. Overall 1997). Several highly aggressive breeds have been identified (Podberscek and Serpell 1996, 1997; Stafford 2007) and they are in decline in some countries. Aggression often results in bites, both to other dogs (Baranyiová et al. 2004, Döring et al. 2006) and bites to people (Weiss et al. 1998). The latter lead not only to physical and psychological trauma to the victim, especially when children are bitten (Náhlík 2005; Náhlík et al. 2006ab) but, also pose a serious public health concern (Weiss et al. 1998; De Keuster et al. 2006; Shuler et

Address for correspondence:

E. Baranyiová

University of Veterinary and Pharmaceutical Sciences

Palackého 1-3, 61242 Brno

Czech Republic

Phone: +420 54156279

E-mail: actavet@vfu.cz

http://www.vfu.cz/acta-vet/actavet.htm 
al. 2008). Because of behaviour problems millions of dogs world-wide are relinquished to shelters and euthanised (Patronek et al. 1996; Stafford 2007).

Although it has long been known that there are specific behavioural traits in breeds of dogs as described in the five breeds studied by Scott and Fuller (1965), or other traits, such as eye-stalking in border collies (Coppinger and Coppinger 2001), it was not until 20 years later that breed-specific behaviours in the most popular breeds and their behavioural traits were categorised in the US (Hart and Hart 1985, 1988) and later in the UK and Italy (Bradshaw et al. 1996; Notari and Goodwin 2007). Several dog breeds have been identified as unsuitable for companion animals (Bradshaw et al. 1996).

Dog ownership in the Czech Republic has features similar to those in other countries as shown in an introductory paper (Baranyiová et al. 2001). For example, the vast majority of dogs are kept as companion animals $(97.7 \%)$, owners communicate with them daily (97.4\%), and take their photographs (97.1\%). Dog owners further assume that their dogs are able to decipher human behaviour $(96.1 \%)$, and vice versa, that they do understand the behaviours and moods of their dogs $(95.4 \%)$. The dogs were described by their owners as devoted $(82.0 \%)$, playful $(86.6 \%)$, protective of household members and possessions $(71.8 \%)$, obedient $(66.6 \%)$, but sometimes disobedient $(57.4 \%)$, stubborn $(40.3 \%)$, difficult to control (21.6\%), and too active (63.6\%). Various aggressions were also reported (Baranyiová et al. 2001).

Further analysis of this set of data on 246 dogs revealed that some of the variables under study significantly depend on the age of the dogs. For example, the youngest dogs (up to one year of age) showed higher locomotor activity (similar to data of Beaudet et al. 1994), more often soiled in the house, destroyed household items and gardens, mounted people and masturbated. Young dogs were never described as nervous. They were fed at least twice a day and when people played with them, tug-of-war games were used most frequently. Middle-aged dogs were more often than others described as obedient and dominant and household members gave them treats more often. Old dogs were found to be nervous, stole human food, were more difficult to control, and vocalised - whined, barked and howled. They were more frequently described as protective of household members and possessions. When walked in the streets, they were more often than others not on the leash, the least active, and did not destroy house furniture and equipment (Baranyiová et al. 2004).

We further found that some of the behavioural traits are influenced by the environment. The dogs under study were exposed to physical and social circumstances and pressures in different ways. They lived either in family houses with yards/gardens or in apartments in towns and cities. They were walked for exercise and elimination. Urban dogs used furniture significantly more frequently than dogs in rural households (Baranyiová et al. 2005), they slept in beds of household members, occasionally attempted to mount them, or growled at them, reportedly perceived the moods of owners and were also fearful. It is obvious that in urbanised environment the coexistence of dogs and people was much more intensive and intimate (Baranyiová et al. 2005).

Our group of dogs was not homogenous, differing in age, breed as well as in size. Because we do not know whether and how this fact may influence their bond to people, we analysed it this time with respect to the various body sizes of the dogs.

\section{Materials and Methods}

Data on dogs were collected from a questionnaire based on Askew (1997) and Podberscek and Serpell (1997), modified for our needs. The questionnaire was published in a monthly magazine „Náš pes“ (Our Dog). The same set of primary data was used as in previous papers reporting on other aspects of the human-dog coexistence (Baranyiová et al. 2001, 2004, 2005, 2007). About 90\% of data came from its readers and the rest was obtained from clients of several veterinary practices. 
The set of 246 dogs was divided by the reported breed into five groups: toy ( $\mathrm{T}$, up to $5 \mathrm{~kg}, \mathrm{n}=32$ ), small (S, $5-10 \mathrm{~kg}, \mathrm{n}=52)$, medium size (M, $10-17 \mathrm{~kg}, \mathrm{n}=39)$, large ( $\mathrm{L}, 17-32 \mathrm{~kg}, \mathrm{n}=70)$, and giant (G, more than 33 $\mathrm{kg}, \mathrm{n}=53)$, (Lewis et al. 1987; Kraft 1998). The data from the questionnaire were used as needed. We studied the frequencies of dog behaviours and conduct of the dog's owners. Relations between variables were evaluated by chi-square test (SPSS v. 13). Standardized residuals are displayed when necessary.

\section{Results}

In this set of data we found that among 84 traits, only 23 , i.e. $27.4 \%$ were related to body mass of the dogs.

Most of the traits did not differ among the dog groups. The dogs were also described as playful (96\%), devoted $(95.7 \%)$, obedient $(86.8 \%)$, but occasionally also disobedient $(59.7 \%)$, dominant $(46.8 \%)$, fearful $(41.5 \%)$, perceived as nuisance $(26.8 \%)$, not active $(20.3 \%)$ and nervous $(20.1 \%)$. No significant differences among the five body size groups were found in playfulness. However, some traits were related to body size. Giant $(\mathrm{G})$ dogs were more frequently than others considered as protective of household members and possessions (Table 1). Toy (T) dogs were more frequently seen as submissive and masturbating (Table 1), small (S) dogs were more frequently seen as stubborn (Table 1), and Large (L) dogs as difficult to control (Table 1).

Dogs of all sizes were reported to show other behaviours perceived as undesirable. They stole food (47.2\%), barked and growled at unknown people (43.2\%), licked and scratched themselves excessively $(41.6 \%)$, ate faeces $(40.2 \%)$, attempted to mount people $(30.8 \%)$, in general, they were too noisy (whined, growled and barked $-25.4 \%$ ), growled at household members $(16.2 \%)$ and bit them (10.7\%). Aggressiveness was also mentioned, when the dog was threatened $(46.2 \%)$, when disturbed from sleep $(11.1 \%)$, when eating $(11.1 \%)$, when pushed $(7.5 \%)$, when reached toward $(4.9 \%)$ and when touched $(3.4 \%)$. The dogs also destroyed gardens $(23.1 \%)$, household objects $(17.7 \%)$, soiled in the apartment $(17.8 \%)$ and roamed $(10.2 \%)$.

The environments, in which the dogs lived, differed in the numbers of persons, presence of children and other animals. Neither the number of adults and children $(55.2 \%$ households had no children) nor the presence of other animals affected significantly the distribution of dogs by their size. Other dogs were present in $50.0 \%$ of households, cats in $27.8 \%$ of them, guinea pigs in $6.4 \%$, parrots in $4.2 \%$ and other vertebrates in $22.7 \%$ households. However, in some traits, significant differences related to body mass were found: the body size $/$ mass was related to the number of household members. In one-person households $5.3 \%$ dogs were kept, but the proportion of T and S dogs was higher: $25.0 \%$ of T dogs and $12.0 \%$ of $\mathrm{S}$ dogs were kept in one-person households $\left(\chi^{2}=18.911, \mathrm{df}=8, p<0.05\right)$.

The type of housing proved to be significantly related to size $\left(\chi^{2}=31.080, \mathrm{df}=8, p<\right.$ $0.001)$. In apartments more $\mathrm{M}$ dogs were kept (52.2\%), in houses with no gardens or yards $\mathrm{S}$ dogs $(9.8 \%)$, and in rural houses with yards or gardens $\mathrm{L}$ dogs $(72.7 \%),\left(\chi^{2}=31.080\right.$, df $=8, p<0.001)$.

An important variable proved to be the age of puppies when acquired; $24.3 \%$ of puppies were older than 6 weeks, however, for $\mathrm{M}$ dogs this number was $77.4 \%$. At the age of more than 6 months, only $8.2 \%$ of dogs were acquired but among them were four times more $\mathrm{T}$ dogs, namely $33.3 \%\left(\chi^{2}=23.611\right.$, df $\left.=8, p<0.005\right)$. Morbidity averaged $56.9 \%$ and was not related to the body size.

Feeding practices did not differ with size of the dog. All dogs were fed once $(57.7 \%)$, twice $(31.8 \%)$ or several times $(10.5 \%)$ per day, and $84.0 \%$ were fed before the family meals. Table scraps were offered only rarely $(4.6 \%)$. Almost all dogs had permanent access to drinking water $(98.9 \%)$, and household members shared their human titbits with their dogs $(80.1 \%)$. Providing tidbits during family meals was related to body size (Table 1$)$.

Relations to size were noted in walking the dogs for exercise and elimination (Table 1). 
$\mathrm{M}$ dogs were taken for walks more frequently than $\mathrm{L}$ or $\mathrm{G}$ dogs. However, their body mass did not affect their being walked always on leash $(12.3 \%)$ or only in the streets $(78.7 \%)$, in park or in forest $(5.6 \%)$.

Play belongs to the basic elements of care for dogs. There were no differences found in types of games and body size of dogs. The owners played with their dogs at home $(79.9 \%)$, during walks $(74.3 \%)$, some of them only occasionally $(32.8 \%)$. The types of games were tug-of-war (72.8\%), other power games (31.7\%) and other types of games $(72.3 \%)$. Fetch type of game was preferred by owners of L dogs $\left(80.9 \% ; \chi^{2}=9.414\right.$, $\left.\mathrm{df}=4, p<0.05\right)$. Almost nine tenths of the dogs $(88.1 \%)$ without differences in size played with other dogs occasionally $(54.5 \%)$, often $(27.2 \%)$ and regularly $(10.4 \%)$.

Some of the dogs were trained, however, in differentiated ways (Table 1): G and L dogs were trained more often than $\mathrm{T}$ and $\mathrm{S}$ dogs. The body size significantly influenced whether or not a professional trainer was used (Table 1). These were employed more often for $\mathrm{L}$ dogs than for $\mathrm{S}$ and $\mathrm{G}$ dogs. $\mathrm{L}$ dogs were more often rewarded with treats $(78.6 \%)$ during training than $\mathrm{S}$ dogs $\left(59.6 \% ; \chi^{2}=11.035 \%\right.$, df $\left.=4, p<0.05\right)$. Obeying the basic commands differed among the five body sizes $\left(\chi^{2}=28.984\right.$, $\mathrm{df}=12, p<$ $0.005)$. The command "sit" was more often obeyed by L dogs $(83.9 \%)$ always, S dogs obeyed sometimes $(28.6 \%)$ or occasionally $(14.3 \%)$. Similar results were obtained with the command "down" $\left(\chi^{2}=38.698, \mathrm{df}=12, p<0.001\right): \mathrm{G}(68.7 \%)$ and $\mathrm{L} \operatorname{dogs}(65.5 \%)$ followed this command always, $\mathrm{T}$ dogs only sometimes $(71.4 \%)$ and $\mathrm{S}$ dogs rarely $(33.0 \%)$.

Table 1. Traits of dogs as reported by their owners

\begin{tabular}{|c|c|c|c|c|c|c|}
\hline \multirow[t]{2}{*}{ Trait } & \multicolumn{5}{|c|}{ Body size } & \multirow[t]{2}{*}{ Significance } \\
\hline & Toy & Small & Medium & Large & Giant & \\
\hline The dog is protective & 66.7 & 68.8 & 80.4 & 80.7 & 100 & $\chi^{2}=10.319(p<0.05)$ \\
\hline Std. Residuals & -0.8 & 2.4 & 0.6 & 1.0 & 2.3 & \\
\hline The dog is submissive & 87.5 & 41.9 & 25.8 & 25.5 & 30.0 & $\chi^{2}=14.378(p<0.005)$ \\
\hline Std. Residuals & 3.1 & 1.5 & -1.3 & -1.8 & -0.4 & \\
\hline The dog is masturbating & 44.4 & 20.2 & 12.2 & 9.5 & 20.0 & $\chi^{2}=10.025(p<0.05)$ \\
\hline Std. Residuals & 2.4 & 1.4 & -0.8 & -2.0 & 0.5 & \\
\hline The dog is stubborn & 25.0 & 52.4 & 69.2 & 44.1 & 38.5 & $\chi^{2}=9.369(p<0.05)$ \\
\hline Std. Residuals & -1.5 & 0.3 & 2.5 & -1.3 & -1.0 & \\
\hline The dog is sometimes difficult to control & 0.0 & 12.6 & 20.0 & 27.9 & 5.0 & $\chi^{2}=11.934(p<0.05)$ \\
\hline Std. Residuals & -1.4 & -1.7 & 0.4 & 2.9 & -1.6 & \\
\hline The dog is given tidbits & 33.3 & 37.9 & 21.6 & 13.5 & 20.0 & $\chi^{2}=15.641(p<0.005)$ \\
\hline Std. Residuals & 0.6 & 3.6 & -0.6 & -3.1 & -0.5 & \\
\hline The dog is taken to exercise and eliminate & 55.6 & 77.6 & 78.4 & 56.8 & 45.0 & $\chi^{2}=17.112(p<0.005)$ \\
\hline Std. Residuals & -0.8 & 2.6 & 1.8 & -2.7 & -2.3 & \\
\hline The dog is trained by owner & 12.5 & 42.3 & 64.0 & 71.6 & 78.9 & $\chi^{2}=27.491(p<0.001)$ \\
\hline Std. Residuals & -2.6 & -4.0 & 1.0 & 3.2 & 1.9 & \\
\hline The dog is professionally trained & 0.0 & 2.2 & 22.9 & 34.1 & 15.0 & $\chi^{2}=33.314(p<0.001)$ \\
\hline Std. Residuals & -1.3 & -4.9 & 1.1 & 4.8 & -0.3 & \\
\hline The dog is allowed to sleep in bed & 100.0 & 81.6 & 54.9 & 35.2 & 30.0 & $\chi^{2}=54.319(p<0.001)$ \\
\hline Std. Residuals & 2.6 & 6.0 & -0.5 & -5.3 & -2.6 & \\
\hline The dog is allowed to use furniture & 100.0 & 93.9 & 74.5 & 57.3 & 45.0 & $\chi^{2}=45.938(p<0.001)$ \\
\hline Std. Residuals & 1.8 & 5.6 & 0.0 & -4.6 & -3.2 & \\
\hline The dog perceives moods of the owner & 100.0 & 96.9 & 100.0 & 91.0 & 85.0 & $\chi^{2}=10.604(p<0.05)$ \\
\hline Std. Residuals & 0.7 & 1.2 & 1.9 & -1.9 & -2.0 & \\
\hline The owner perceives moods of the dog & 100.0 & 98.0 & 94.0 & 91.0 & 80.0 & $\chi^{2}=11.022(p<0.05)$ \\
\hline Std. Residuals & 0.8 & 2.2 & 0.1 & -1.2 & -2.6 & \\
\hline
\end{tabular}


Almost all dogs $(99.6 \%)$ were clearly integrated in the household. They were considered household members. Regardless of their size they were taken on travels and vacations $(83.7 \%)$, people had their photographs $(94.8 \%)$, and celebrated their birthdays $(72.1 \%)$. A relationship between body size and the position, social function of the dogs in households was observed in some traits. S dogs were more often $(91.2 \%)$ viewed as companions (in the entire set of data it was $77.0 \%$ ) whereas $\mathrm{L}$ dogs in contrast to others $(21.5 \%)$ were considered not only companions but also as working dogs $(38.6 \%)\left(\chi^{2}=36.263\right.$, $\mathrm{df}=8, p$ $<0.001$ ). Sleeping of dogs in owner's beds was significantly related to body size (Table 1): $\mathrm{T}$ dogs $(100.0 \%)$ and $\mathrm{S}$ dogs $(81.6 \%)$ were allowed to sleep in beds of their owners more frequently than $\mathrm{L}$ dogs $(35.2 \%)$ and $\mathrm{G}$ dogs (30.0\%). Similar findings concerned dogs using furniture. All T dogs and nearly all $\mathrm{S}$ dogs were allowed to use it (Table 1). All T and $\mathrm{M}$ dogs were reported to perceive the moods of their owners (Table 1). People claimed to perceive the moods of their dogs; more so in T and S than in G dogs (Table 1).

\section{Discussion}

In our data set the smallest dogs weighed less than $5 \mathrm{~kg}$ and the largest ones weighed more than $33 \mathrm{~kg}$. Thus the largest animals surpassed at least seven times the body mass of the smallest ones. The lightest among the $\mathrm{G}$ dogs weighed roughly about one half but also more, and $\mathrm{T}$ dogs weighed less than one tenth of the mean body mass of humans of the Czech population. Despite this fact the majority of the traits under study documenting the mutual interactions of people and dogs did not differ significantly, not even in aggression as reported more often by our respondents than diagnosed by other authors (Beaver 1994; Houpt et al. 1996; Takeuchi et al. 2001; Anonymous 2002). No significant differences among dogs belonging to the five body size groups were detected and the data presented in this paper correspond with those published earlier (Baranyiová et al. 2001, 2004, 2005).

The size of the dogs affected significantly only one fourth of the traits under study. For example, $\mathrm{T}$ dogs were more often characterised, in contrast to other sizes, as submissive and masturbating. Only one eighth of them were given any training and they obeyed the commands only sometimes or rarely. They were more often kept in one-member households and were mostly acquired at an age older than six months. They were allowed to sleep in beds more often than others.

$\mathrm{S}$ dogs were more frequently viewed as showing less locomotory activity, and as companions. People in households with $\mathrm{S}$ dogs were more likely to be convinced that they understood the behaviours and moods of their dogs than people in households with dogs of other sizes. The S dogs were only rarely given any training and no trainers were engaged, no treats were used for rewards. Not surprisingly, they did not obey the commands well. They were mostly acquired at an age older than 6 weeks, and kept in households with several members, situated in urban apartments. They were allowed to sleep in beds and use furniture. They were given food during the family meals, and occasionally during the day, and also treats.

$\mathrm{M}$ dogs showed the least number of significant differences from other sizes. They were more often characterised as active and stubborn. Their owners felt that their dogs were able to perceive their moods. They were more often kept in one-person households in apartments with no yards available.

$\mathrm{L}$ dogs were more often viewed as obedient, but also more active and sometimes difficult to control. However, they were more frequently given training, also under the guidance of trainers. Treats were used as rewards, and they were more reliable in obeying commands. They perceived less the moods of their owners. Only these dogs were kept as companions and also as working dogs, more often in houses with yards or gardens, in rural environments as pointed out in our previous paper (Baranyiová et al. 2005). They were rarely allowed to sleep in beds 
and use furniture. They were more often given food from the table and treats. When playing with their dogs, the owners preferred fetch-type of games. These dogs were taken for walks less frequently than M and S dogs (Table 1); this fact may be connected with availability of garden/ yard space for exercise and elimination, similar to $\mathrm{G}$ dogs.

$\mathrm{G}$ dogs were reported as less active. They were characterised as obedient and protective of household members. They reportedly perceived less the moods of the owners but the owners perceived their moods less as well. Fewer of these dogs were allowed to sleep in beds or use furniture. They were less often taken for walks.

Possible direct relationships in our set of data can be found between the body mass of dogs and the type of housing of their owners. L and $\mathrm{G}$ dogs were more frequently reared in areas with more space, in houses with yards and gardens, in rural environments. On the other hand, T and $\mathrm{S}$ dogs were more numerous in urban areas, in dwellings from which they were only taken for walks and elimination. The fact that these dogs shared relatively smaller spaces of apartments with their owners lead to a very close co-existence of the two species, which was pointed out earlier (Baranyiová et al. 2005) and was confirmed in the present analysis. T dogs were kept mostly in one-person households, i.e. in a socially less complicated environment.

It seems that as these dogs are kept mostly for company, people tend towards anthropomorphic attitudes possibly keeping their dogs as substitutes for the companionship of humans. They obviously do not perceive a need to train and control them in various situations. Such lack of control may have negative consequences; for example, these dogs are more often involved in dog bite incidents with children (Náhlík 2005; Náhlík et al. $2006 \mathrm{ab}$ ) than large or giant dogs. Family dogs bit mostly at home, and bites by S dogs were the most frequent ones (Náhlík et al. 2006).

L dogs were more often trained, and trainers were involved in training. Obviously, owners of these breeds are well aware of the need to control their dogs. These dogs were obedient, protective of the owners and their possessions, and were used as working dogs, too. Similar results were reported for Doberman Pinchers in Germany that were usually housed in rural areas and had an exceptionally high training level, examinations and nearly all had good basic obedience training (Döring et al. 2006).

The bond of people and dogs that began thousands of years ago (Savolainen et al. 2002), had and continues to have a complicated development. Archaeological findings (Nobis 1979, Clutton-Brock 1995) provide evidence, as recently summarised by Morey (2006), that dogs used to be ritually buried 12 to 14 thousand years ago and that their craniometric data have already shown changes in the size, paedomorphosis, and juvenile morphology (Morey 1992). These changes thus cannot be ascribed to the later selection pressures dictated by practical needs of shepherds and farmers. More recently, the breeding objectives were set out, changed and abandoned so that the end result was an even greater phenotype diversification also in the body sizes of dogs. At present, the dog breeds may differ as much as $68 \mathrm{~kg}$ in body mass (Case 2005), i.e. the differences may be 100 fold (Burger and Johnson 1991). Aim-specific selection of dogs continues in attempts to standardise modern breeds of dogs (Clutton-Brock 1995; Hart 1995; Willis 1995; Lindsay 2000; Coppinger and Coppinger 2001; Case 2005; Svartberg 2006). Such trends occur also in this country which is undergoing major changes in life style. This leads to new attitudes in evaluating dogs and their behaviour. People want to keep dogs above all for companionship in both rural and urban environments. The breeding aim is no more a canine co-worker and helper but rather a pet (Bergler 1988). Even if the dogs are extremely diverse in phenotype, small and large, they are successful in fulfilling this unusual social function, the bond with human partners living in a post-industrial information age. The domestication process and development of the human-dog bond continues to develop. Great variability in their body mass is not an obstacle in this process and they obviously possess a remarkable diversification potential. 


\section{Projevy chování různě velkých psů v českých domácnostech}

Předmětem našeho zájmu byl tentokrát vliv velikosti psů na jejich soužití s lidmi v českých domácnostech. Proto jsme z výchozího soubor psů, jímž se opakovaně zabýváme, vyjmuli 246 jedinců a rozdělili je do pěti skupin dle živé hmotnosti na trpasličí (T) (do $5 \mathrm{~kg}, \mathrm{n}=32$ ), malé $(\mathrm{M})($ od 5 do $10 \mathrm{~kg}, \mathrm{n}=52)$, stř́ední (S) (od 10 do $17 \mathrm{~kg}, \mathrm{n}=39)$, velké (V) (od 17 do $33 \mathrm{~kg}, \mathrm{n}=70)$ a obří (O) (nad $33 \mathrm{~kg}, \mathrm{n}=53)$. V tomto uspořádání byli psi největší nejméně sedmkrát těžší než nejmenší a psi obří vážili aspoň polovinu a psi trpasličí méně než jednu desetinu průměrné hmotnosti lidí v české populaci. Přesto většina sledovaných znaků, bez ohledu na psí hmotnost a její vztah $\mathrm{k}$ hmotnosti členů domácností nevykazovaly průkazné rozdíly. V naprosto převážné většině $\mathrm{v}$ českých domácnostech byli nerozdílně pokládáni za členy domácností, brali se na cesty či dovolené, fotografovali se a slavili jejich narozeniny. Ani jejich agresivnost nebyla velikostí významně ovlivněna.

Z 84 charakteristik chování psů a jednání lidí, které jsme sledovali, jich mělo k hmotnosti psů statisticky významný vztah jen 23, tj. 27,4 \%. Psi obou těžších kategorií byli častěji chováni v domech s výběhy, na dvorcích a zahradách, tedy v rustikálním prostředí, zatímco psi trpasličí a malí v prostředí urbanizovaném, v př́bytcích, z nichž byli vyváděni jen na procházky a venčeni. Častěji využívali bytové vybavení a spali v postelích členů domácností. Nelze opomenout, že psi trpasličí žili častěji v domácnostech jednočlenných.

Psům velkým se pak častěji dostávalo výcviku, i pod vedením cvičitelů, lépe plnili povely a byli poslušní. Byli označováni nejen jako společníci, ale i jako psi pracovní. Psi obř́i byli rovněž více cvičeni a pokládáni i za ochranáře.

$\mathrm{Z}$ uvedených údajů je patrno, že rozdíly v hmotnosti psů modifikovaly jejich soužití $\mathrm{s}$ lidmi procházejícími závažnými změnami životního slohu jen v omezeném rozsahu.

\section{Acknowledgements}

The study was partly supported by the MŠMT projects FRVŠ 1471/2004 and 1823/2005.

\section{References}

Anonymous 2002: Behavioural problems in cats and dogs. Vet Rec 151: 252

Askew HR 1997: Behandlung von Verhaltensproblemen bei Hund und Katze. Parey, Berlin. VII and 372 p.

Baranyiová E, Holub A, Janáčková B, Ernstová M 2001: Výpovědi chovatelů o psech v České republice. In Czech. (Owner-reported behaviour of dogs in the Czech Republic). Veterinářství 51: 167-171

Baranyiová E, Holub A, Tyrlík M, Janáčková B, Ernstová M 2004: Behavioural differences of dogs of various ages in Czech households. Acta Vet Brno 73: 229-233

Baranyiová E, Holub A, Tyrlík M, Janáčková B, Ernstová M 2005: The influence of urbanization on the behaviour of dogs in the Czech Republic. Acta Vet Brno 74: 401-409

Baranyiová E, Holub A, Tyrlík M 2007: Behavioural traits of four dog breeds in Czech Households. Acta Vet. Brno 76: 627-634

Beaudet R, Chalifoux A, Dallaire A 1994: Predictive value of activity level and behavioural evaluation on future dominance in puppies. Appl Anim Behav Sci 40: 273-284

Beaver BV 1994: Owner complaints about canine behavior. J Amer Vet Med Assn 204: 1953

Bergler R 1988: Man and dog. The psychology of a relationship. Oxford. $188 \mathrm{p}$.

Bradshaw JWS, Goodwin D, Lea AM, Whitehead SL 1986: A survey of the behavioural characteristics of purebred dogs in the United Kingdom. Vet Rec 138: 465-468

Burger IH, Johnson JV 1991: Dogs large and small - the allometry of energy requirements within a single species. J Nutr 121, Suppl.: S18-S21

Case LP 2005: The dog. Its behavior, nutrition, and health. Second edition. Blackwell Publishing, Oxford. 479 p.

Clutton-Brock A 1995: Origins of the dog: domestication and early history. In: The domestic dog: its evolution, behaviour and interactions with people. Cambridge University Press, Cambridge 1995. p. 7-20

Coppinger R, Coppinger L 2001: Dogs. A new understanding of canine origin, behavior, and evolution. University of Chicago Press, Chicago. p. 352

De Keuster T, Lamoureux J, Kahn A 2006: Epidemiology of dog bites: A Belgian experience of canine behaviour and public health concerns. Vet J 172: 482-487 
Döring D, Satter D, Erhard MH, Unshelm J 2006: Dobermannhaltung in Deutschland: Ergebnisse einer Befragung. Teil 1: Aufzucht, Haltung und Erziehung der Hunde sowie Einstellung der Besitzer. Tierärztl Prax 34: $172-177$

Flannigan G, Dodman NH 2001: Risk factors and behaviors associated with separation anxiety in dogs. J Amer Vet Med Assn 219: 460-466

Hart BL 1995: Analysis of breed and gender differences in behaviour. In: The Domestic Dog: its evolution, behaviour and interactions with people. Cambridge University Press,Cambridge. pp. 65-77

Hart BL, Hart LA 1985: Selecting pet dogs on the basis of cluster analysis of behavioral profiles and gender. Am J Vet Med Assoc 186: 1181-1185

Hart BL, Hart LA 1988: The perfect puppy. How to choose your dog by its behavior. W.H. Freeman and Company, New York, $182 \mathrm{p}$.

Houpt KA, Honig SU, Reisner I 1996: Exploring the bond - Breaking the human companion animal bond. J Amer Vet Med Assoc 208: 1653-1659

Kraft W 1998: Einführung. In: Geriatrie bei Hund und Katze. Parey Verlag, Berlin. p. 1-26

Lewis LD, Morris ML Jr, Hand MS 1987: Small Animal Clinical Nutrition. III. Ed, Mark Morris Assoc, Topeka, Kansas

Lindsay SR 2000: Handbook of dog behavior and training. Adaptation and learning. Vol. I. Iowa State University Press, Ames

Luescher AU 2002: Compulsive behaviour. In: Horwitz D, Mills D, Heath S (Eds): BSAVA Manual of Canine and Feline Behavioural Medicine. BSAVA, UK, pp. 229-236

Luescher AU 2003: Diagnosis and management of compulsive disorders in dogs and cats. In: Houpt KA, Virga V (Eds): Update on Clinical Veterinary Behavior. Vet Clin North Amer Small Anim Pract 33 (No. 2): 253-267

Morey DF 1992: Size, shape and development in the evolution of the domestic dog. J Archeol Sci 19: 181-204

Morey DF 2006: Burying key evidence: the social bond between dogs and people. J Archeol Sci 33: 158-175

Náhlík J, Baranyiová E, Tyrlík M 2006: Dog bites to children in the Czech Republic. Proceedings of the $40^{\text {th }}$ International Congress of the ISAE, University of Bristol (ed. M. Mendl et al.), p. 83

Náhlík J, Baranyiová E, Tyrlík M 2006: Dog bites to children in the Czech Republic - a survey. 2006 World Congress WSAVA/FECAV/CSAVA Proceedings, pp. 872-873

Náhlík J 2005: Výpovědi českých dětí o kousnutí psem. In Czech. (Report on dog bites of Czech children). MVDr. Thesis, University of Veterinary and Pharmaceutical Sciences Brno, $74 \mathrm{p}$.

Nobis G 1979: Der älteste Haushund lebte vor 14.000 Jahren. Umschau 19: 610

Notari L, Goodwin D 2007: A survey of behavioural characteristics of pure-bred dogs in Italy. Appl Anim Behav Sci 103: 118-130

Overall K 1997: Clinical Behavioral Medicine for Small Animals. Mosby, St. Louis, 544 p.

Patronek GJ, Glickman LK, Beck AM, McCabe GP 1996: Risk factors for relinquishment of dogs to an animal shelter. J Amer Vet Med Assn 209: 572-581

Podberscek AL, Serpell JA 1996: The English Cocker Spaniel: preliminary findings on aggressive behaviour. Appl Anim Behav Sci 47: 75-89

Podberscek AL, Serpell JA 1997: Environmental influences on the expression of aggressive behaviour in English Cocker Spaniels. Appl Anim Behav Sci 52: 215-227

Savolainen P, Zhang YP, Luo J, Lundeberg J, Leitner T 2002: Genetic evidence for an East Asian origin of domestic dogs. Science 298: 1610-1613

Scott JP, Fuller JL 1965: Dog behavior. The Genetic Basis. University of Chicago Press.

Shuler CM, Debess EE, Lapidus JA, Hedberg, K 2008: Canine and human factors related to dog bite injuries. J AmVet Med Assoc 232: 542-546

Stafford K 2007: The Welfare of Dogs. Springer, 280 p.

Svartberg K 2006: Breed-typical behaviour in dogs - Historical remnants or recent constructs? Appl Anim Behav Sci 96: 293-313

Takeuchi Y, Ogata N, Houpt KA, Scarlett JM 2001: Differences in background and outcome of three behavior problems of dogs. Appl Anim Behav Sci 70: 297-308

Weiss HB, Friedman DI, Coben JH 1998: Incidence of dog bite injuries treated in emergency departments. J Am Med Assoc 279: $51-53$

Willis MB 1995: Genetic aspects of dog behaviour with particular reference to working ability. In: The Domestic Dog: its evolution, behaviour and interactions with people. Cambridge University Press, Cambridge, pp. 51-64 